Note Open Access

\title{
Biocontrol of Tomato Fusarium Wilt by a Novel Genotype of 2,4-Diacetyl- phloroglucinol-producing Pseudomonas sp. NJ134
}

\author{
Beom Ryong Kang* \\ Environment-Friendly Agricultural Research Institute, Jeollanamdo Agricultural Research and Extension Services, Naju 520- \\ 715, Korea \\ (Received on October 26, 2011; Revised on November 21, 2011; Accepted on November 21, 2011)
}

\begin{abstract}
The rhizobacterium NJ134, showing strong in vitro antifungal activity against Fusarium oxysporum, was isolated from field grown tomato plants and identified as Pseudomonas sp. based on 16S ribosomal DNA sequence and biochemical analyses. The antifungal compound purified by gas chromatography-mass spectrometry, infrared, and nuclear magnetic resonance analyses from NJ134 cultures was polyketide 2,4-diacetylphloroglucinol (DAPG). Analysis of the sequence of part of one of the genes associated with DAPG synthesis, phlD, indicated that the DAPG producer NJ134 was a novel genotype or variant of existing genotype termed $O$ that have been categorized based on isolates from Europe and North America. A greenhouse study indicated that about $10^{8} \mathrm{CFU} / \mathrm{g}$ of soil $\mathrm{NJ} 134$ culture application was required for effective biocontrol of Fusarium wilt in tomato. These results suggest that a new variant genotype of a DAPG-producing strain of Pseudomonas has the potential to control Fusarium wilt under the low disease pressure conditions.
\end{abstract}

Keywords : antifungal compound, biological control, genotype

Fusarium wilt caused by Fusarium oxysporum f. sp. lycopersici results in severe losses in tomatoes (Larkin and Fravel, 1998). The first symptom of Fusarium wilt is chlorosis of older leaves, and a browning of vascular tissue that extends up the stem, although the pith remains healthy. Yellowing gradually affects the entire plant, wilting occurs in hot temperatures, and the plant eventually dies (Jones et al., 1991). Nonpathogenic fungal of $F$. oxysporum and $F$. solani collected from a Fusarium wilt-suppressive soil were significantly reduced Fusarium wilt of tomato (Larkin and Fravel, 1998). Antagonists recovered from Fusarium suppressive soils, particularly nonpathogenic $F$. oxysporum reduces Fusarium wilt (Jarvis, 1988). Rhizobacterial com-

\footnotetext{
*Corresponding author.

Phone) +82-61-330-2515, FAX) +82-61-336-4076

E-mail) brkang@korea.kr
}

petent isolates of Pseudomonas and Bacillus spp. also provide disease protection (Larkin and Fravel, 1998). However, a commercially acceptable biocontrol strain is not available. Microorganisms isolated from the root or rhizosphere of a specific crop may be better adapted to that crop and may provide better disease control than organisms originally isolated from other plant species (Cook, 1993).

The antibiotic DAPG is produced by pseudomonads of worldwide origin, and its biosynthetic locus is conserved in pseudomonads obtained from diverse geographic locations. In genetic diversity studies, most of the distinct, DAPG producer groups have been identified from European and US collections (Keel et al., 1996; Landa et al., 2002a; Mavrodi et al., 2001; McSpadden Gardener et al., 2000). Seventeen different phlD genotypes (designated A-Q) have been recognized by BOX-PCR analysis, RFLP-phlD analysis (Landa et al., 2002a; Mavrodi et al., 2001; McSpaddenGardener et al., 2000, 2001), and the clusters defined by different genomic fingerprinting methods or by phylogenetic analysis of $p h l D$ correlate well. However, the actual number of genotypes in soils worldwide and the basis for their biogeography is unknown, and most of the bacteria show a substantial degree of endemicity (McSpadden-Gardener et al., 2001). For example, genotype A has been isolated from birdsfoot trefoil, corn, cotton, cucumber, tobacco, pea, and soybeans from soils in the Czech Republic, Ghana, Italy, Switzerland, Uruguay and various states in the USA (De La Fuente et al., 2006; Landa et al., 2002b; McSpaddenGardener et al., 2000, 2005), whereas genotype D has been isolated from a variety of crops in France, Germany, Spain, Switzerland, and various states in the USA (McSpaddenGardener et al., 2000, 2005). In addition, all genotypes (A, B, D, E, F, G, I, J, L, O, P, T, and Q) present at very low densities have been isolated in soil from pea, wheat, and take-all decline fields throughout the US (McSpadden-Gardener et al., 2000). In biogeography and endemicity of Pseudomonas sp. genotypes, soil heterotrophic bacteria in undisturbed sites are not globally mixed (Cho and Tiedje, 2000).

In this study, bacterial strains that were antagonistic to Fusarium growth were isolated from soils of the tomato cultivated field in Jeollanamdo Province, Korea. Strain 
Table 1. Characterization of Pseudomonas sp. NJ134

\begin{tabular}{|c|c|c|c|c|c|}
\hline & \multirow{2}{*}{ Test } & \multicolumn{2}{|c|}{ NJ134 } & \multicolumn{2}{|c|}{ P. fluorescens } \\
\hline & & 24 hour & 48 hour & 24 hour & 48 hour \\
\hline \multirow{16}{*}{ API test* } & Denitrification (Nitrate reduction) & - & - & - & - \\
\hline & Indole production & - & - & - & - \\
\hline & Fermentation & - & - & - & - \\
\hline & Arginine dihydrolase & + & + & + & + \\
\hline & Urease & - & - & - & - \\
\hline & Hydrolysis ( $\beta$-glucosidase) & - & - & - & - \\
\hline & Hydrolysis (protease) & + & + & + & + \\
\hline & Nitrophenyl- $\beta$ D-galactopyranosidase & - & - & - & - \\
\hline & D-Glucose & + & + & + & + \\
\hline & L-arabinose & + & + & + & + \\
\hline & D-Mannose & + & + & + & + \\
\hline & D-Mannitol & + & + & + & + \\
\hline & N-acetyl-glucosamine & - & - & - & - \\
\hline & D-Maltose & - & - & - & - \\
\hline & Potassium Gluconate & + & + & + & + \\
\hline & Oxidase & + & + & + & + \\
\hline \multicolumn{2}{|l|}{ Cell form } & \multicolumn{2}{|c|}{ Rod } & & \\
\hline \multicolumn{2}{|c|}{ Gram staining } & \multicolumn{2}{|c|}{-} & & \\
\hline \multicolumn{2}{|c|}{ Number of flagella } & \multicolumn{2}{|c|}{$($ polar $)>1$} & & \\
\hline \multicolumn{2}{|c|}{ Endospore production } & \multicolumn{2}{|c|}{-} & & \\
\hline \multicolumn{2}{|c|}{ Fluorescens pigment } & \multicolumn{2}{|c|}{+} & & \\
\hline
\end{tabular}

*API20 NE identification system (BioMérieux, Marcy l'Etoile, France)

NJ134 is a Gram-negative, short rod, motile bacterium with lophotrichous flagellar as observed under transmission electron microscopy (Table 1). It produced a brownish-yellow fluorescent pigment on KB medium. Based on 98\% similarity, the API20 NE identification system (BioMérieux, Marcy l'Etoile, France), which exploits the bacterial utili-

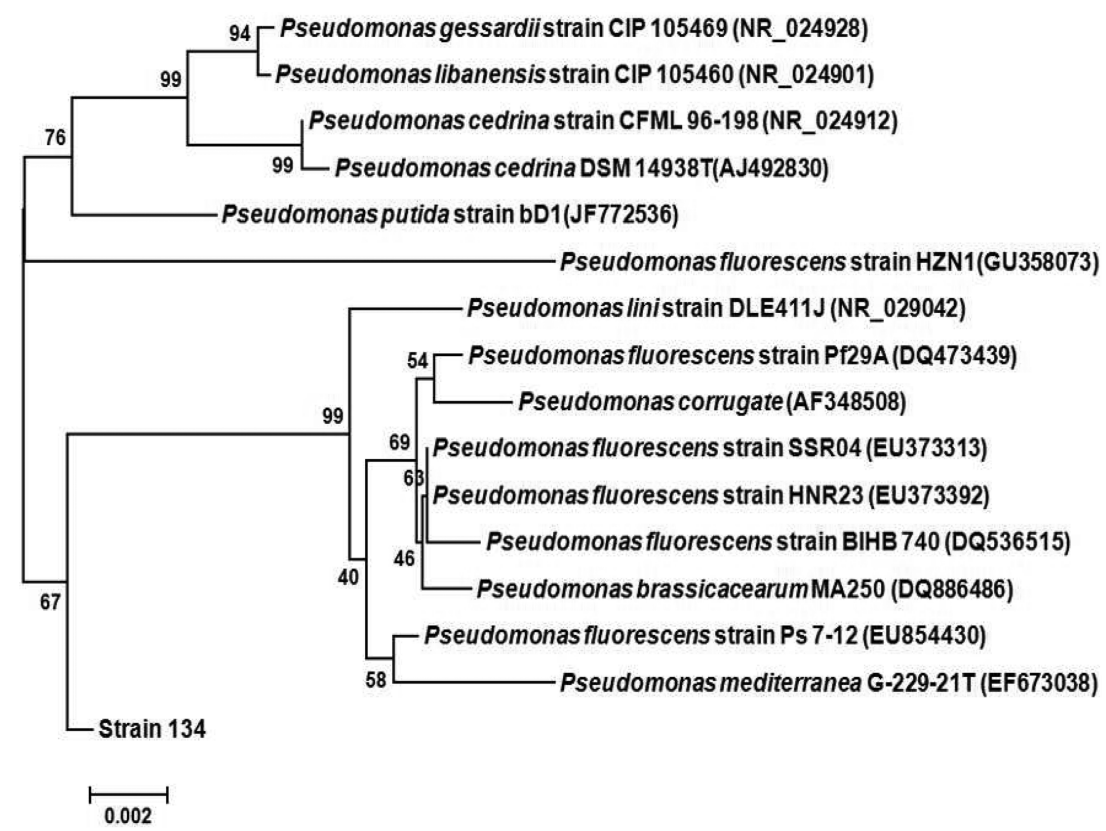

Fig. 1. Neighbor-joining tree showing the phylogenetic relationships of strain NJ134 to other related species based on 16S rDNA gene sequences. Bootstrap values are given in percentages of 1000 replicates. 
zation patterns of various carbon sources, identified the NJ134 as Pseudomonas fluorescens.

NJ134 was biochemically identified by $16 \mathrm{~S}$ rDNA sequence analysis. 16S rDNA was amplified using the fD1 and rP2 universal primers (Weisburg et al., 1991), and their nucleotide sequences were determined. A comparative 16S rDNA sequence analysis of the 1.5-kb PCR product from the NJ134 strain revealed that it formed a distinct lineage in the family Pseudomonadaceae and showed highest nucleotide sequence identity with Pseudomonas.

An almost complete strain NJ134 16S rDNA sequence (1514 nt) was obtained and used for initial BLAST searches in GenBank and for phylogenetic analyses. Strain NJ134 was closely related to recognized species such as Pseudomonas lini and P. fluorescens (Fig. 1).

In vitro antifungal activities of Pseudomonas sp. NJ134, in dual growth with various fungal pathogenic fungi, were determined on PDA (Difco Lab., Detroit, MI, USA) plates.
Strain NJ134 showed strong growth inhibition against $F$. oxysporum and B. cinerea (KACC 40574), causing Fusarium wilt and gray mold on tomato plants, respectively. To determine the major antibiotic compound involved, in vitro inhibition of F. oxysporum, Colletotrichum acutatum (KACC 40042) causing anthracnose, Rhizoctonia solani (KACC 40101) causing "rice" sheath blight, Phytophthora infestans (KACC 40718) and Pyricularia grisea (KACC 40417) was determined (data not shown).

To determine the major antifungal compound of Pseudomonas sp. NJ134, strain NJ134 was grown on modified KB (proteose peptone \#3 $20 \mathrm{~g}, \mathrm{~K}_{2} \mathrm{HPO}_{4} 1.5 \mathrm{~g}, \mathrm{MgSO}_{4} \cdot 7 \mathrm{H}_{2} \mathrm{O} 0.4 \mathrm{~g}$ per $1 \mathrm{~L})$ containing $1 \%(\mathrm{w} / \mathrm{v})$ mannitol at $26^{\circ} \mathrm{C}$ with agitation for 7 days. Our previous work showed that NJ134 cultures showed their highest in vitro antifungal activity when cells were grown in modified King's B medium with mannitol (unpublished result). The crude NJ134 metabolites were extracted by partitioning (1:1 ratio) using different organic

\section{A.}

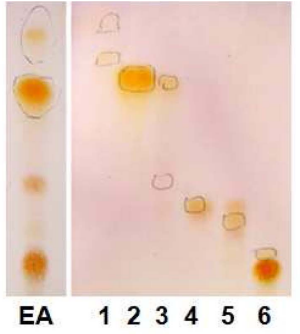

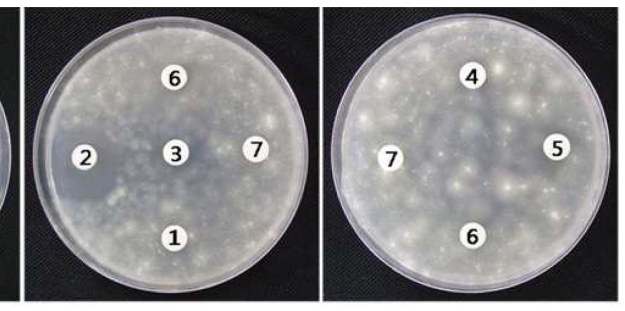

B.

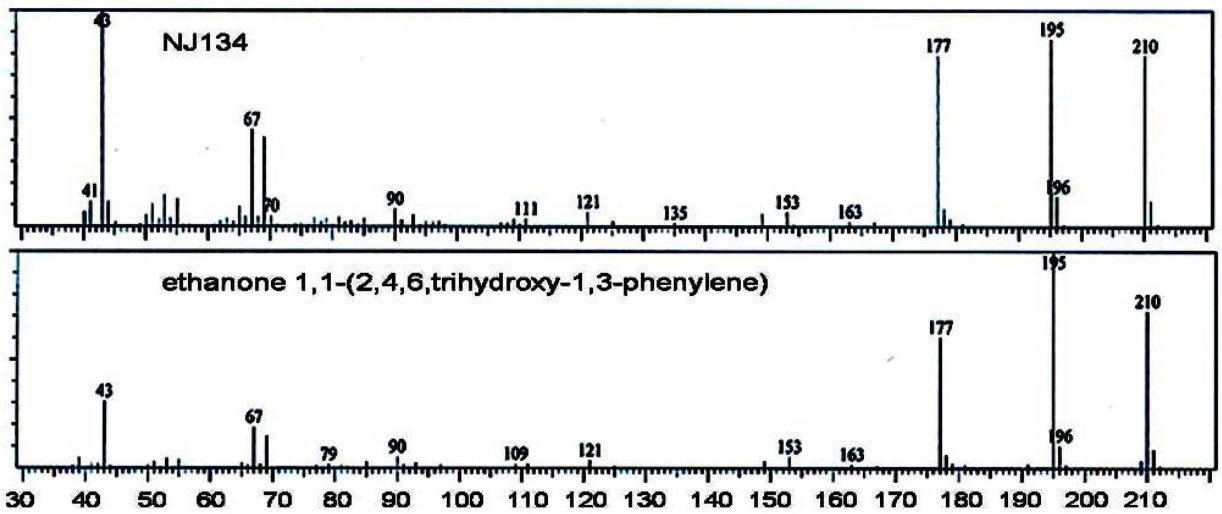

C.<smiles>CC(=O)c1c(O)cc(O)c(C(C)=O)c1O</smiles>

Fig. 2. Identification of the major antifungal metabolite from Pseudomonas strain NJ134. Thin layer chromatography profiles of antifungal metabolites produced by the antagonistic strain NJ134 and inhibition of F. oxysporum mycelia growth with an ethyl acetate (EA) extract (A). 1-6, EA extract; 7, Methanol (Control). Gas chromatography-mass spectrometry spectra of an antifungal antibiotic (B) and the chemical structure of authentic 2,4-diacetylphologlucinol (C). 
solvents. The extracted metabolites were tested (without concentration) for their efficacy against pathogens. Among the metabolites tested against $F$. oxysporum, the ethyl acetateextracted metabolite $\left(\mathrm{R}_{\mathrm{f}} 0.62\right)$ effectively inhibited $81 \%$ of growth at $5 \mathrm{mg} / \mathrm{ml}$ (Fig. 2A). The active antifungal metabolite present in the ethyl acetate extract of the cell-free culture supernatant was purified by preparative thin-layer chromatography (Merck, Darmstadt, Germany). The purified active compound was obtained from a single gas chromatographmass spectrometry (GC-MS) peak with a retention time of 21 min (Shimadzu Prominence, Tokyo, Japan) (Fig. 2B). The structure of the purified antifungal compound was determined by nuclear magnetic resonance (NMR) and mass spectral analysis (Bruker Company, Bad Herrenalb, Germany) (Fig. $3 \mathrm{C})$. The mass spectrum of the isolated compound was matched to that of ethanone 1,1-(2,4,6-trihydroxy-1,3-phenylene) bis, known by the name 2,4-diacetylphloroglucinol
(DAPG). Based on these data in conjunction with ${ }^{1} \mathrm{H}$ and ${ }^{13} \mathrm{C}$ NMR, infrared spectra, melting point, and elemental analyses, the structure was confirmed by the mass spectrum data.

To date, a number of these disease-suppressing antibiotic compounds have been characterized chemically, including nitrogen containing heterocyclic such as phenazines (Brisbane et al., 1987; Gerber, 1969; Thomashow et al., 1990), pyrroltype antibiotics (Hashimoto and Hattori, 1966ab; Imanaka et al., 1965), pyo-compounds (Hays et al., 1945), and indole derivatives (Wratten et al., 1977). A small number of antibiotic-like compounds that do not contain nitrogen have also been isolated from fluorescent pseudomonads (Broadbent et al., 1976). Among these is DAPG, which has been used to control plant root diseases (Haas et al., 1991; Keel et al., 1990).

The importance of 2,4-DAPG production by strain NJ134 is to suppress soilborne plant pathogens in the rhizosphere.

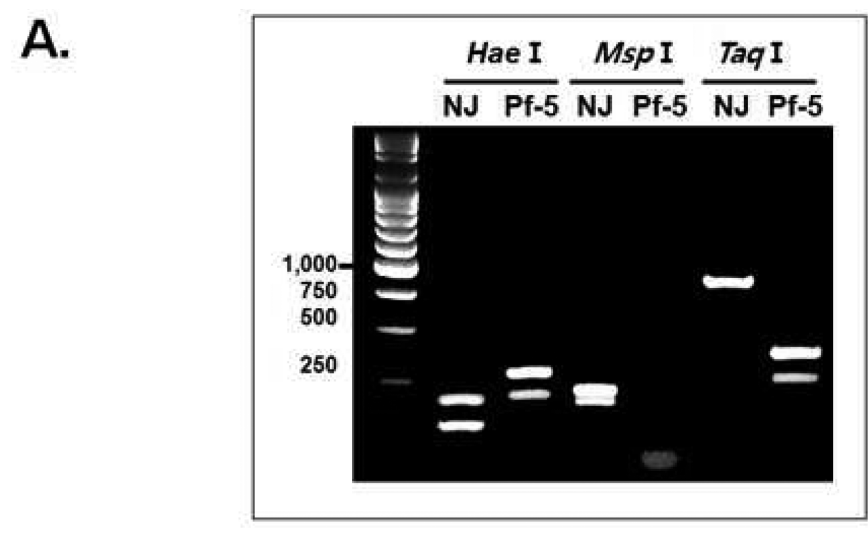

B.

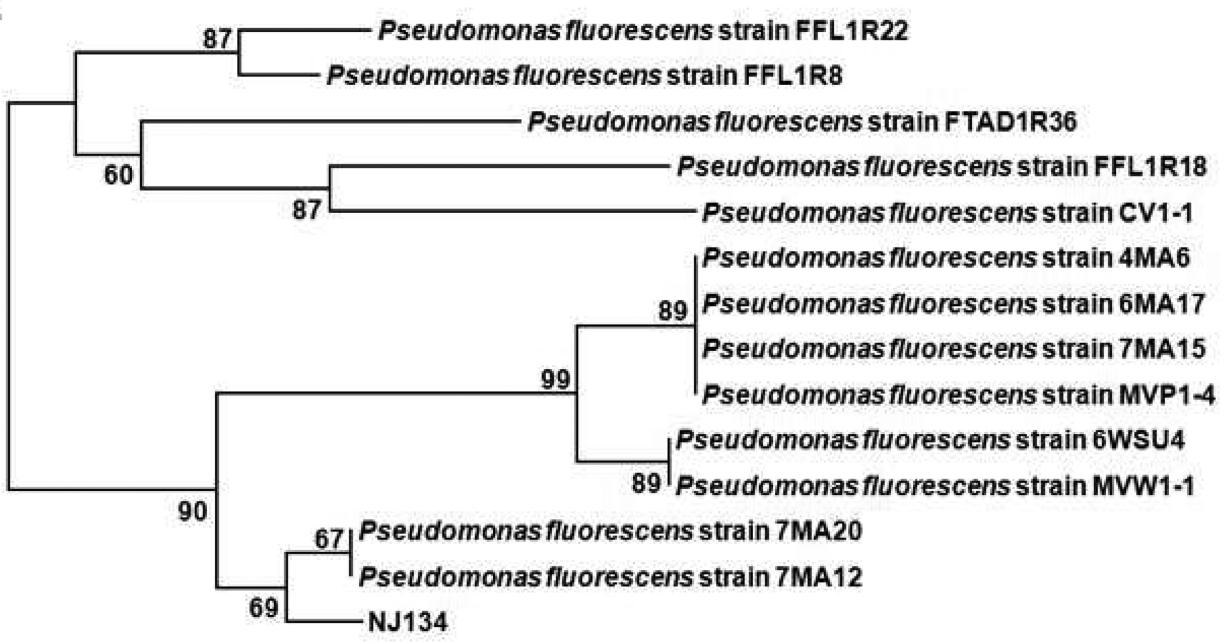

\section{$\stackrel{\vdash}{0.002}$}

Fig. 3. Comparison of the genotype diversity of phlD-containing Pseudomonas fluorescens strain Pf-5 and strain NJ134 defined by phlD gene with Hae III, Msp I, or Taq I (A). Portion of BLAST tree indicating that NJ134 is most closely related to 7MA12 and 7MA20 (genotype O) (B). The next nearest neighbors were those of MVW1-1 (P genotype), which were both detected on pea. Further afield were the FTD1R36 and FFL1R8 groups (genotypes GHIJ). 
GC-MS analysis analyses provided further evidence for its production. To confirm that phlD gene expression leads to an essential phloroglucinol biosynthetic pathway gene, we performed a rapid PCR-based assay targeting phlD (McSpadden-Gardener et al., 2001). To assess the NJ134 genotype based on phlD gene diversity, $16 \mathrm{~S}$ ribosomal DNA gene and phylogenic analyses of the partial phlD gene sequence analysis were conducted, as described previously (McSpadden-Gardener et al., 2001). Restriction fragment length polymorphism (RFLP) analysis of the amplified phlD sequence was used to identify the DAPG genotype (Fig. 3A). The NJ134 strain phlD gene, amplified by PCR-based assay, confirmed the presence of a 626-bp DNA product in the KB culture reaction used as the whole cell template for PCR amplification. The NJ134 product size detected by a phlDspecific primer was quite similar to that determined by producing $P$. fluorescens Pf-5. No RLFPs were found among the 16S rDNA gene sequences from phlD+ strain NJ134 upon digestion with Hae III, Msp I, or Taq I (Fig. 3A). The phlD gene is predicted to encode a polyketide synthase that synthesizes monoacetylphloroglucinol, the immediate precursor to 2,4-DAPG (Dwivedi and Johri, 2003). A conserved portion of the phlD open reading frame has been cloned and sequenced from NJ134 and compared to five genotypically distinct 2,4-DAPG-producing Pseudomonas spp. strains such as CHA0, Pf-5, Q8r1-96, 1M1-96, and Q2-87 (McSpaddenGardener et al., 2001).

Our studies with the NJ134 phlD gene restriction fragment showed a new portion of the DAPG genotype that was used for initial BLAST searches in GenBank. A 626 bp phlD gene fragment from strain NJ134 has been amplified by PCR using the Phl2a and Phl2b primers (McSpadden Gardener et al., 2001). Consensus sequence quality was checked using the translating BLAST function BLASTX (National Center for Biotechnology Information). phlD sequences were aligned using the CLUSTALW service (http://molevol.cmima. csic.es/castresana/Gblocks_server.html). Phylogenetic analyses were performed with MEGA 4.0 software (Tamura et al., 2007) using the neighbor-joining method (Fig. 3B). The BLAST tree of strain NJ134 was most closely related to $P$. fluorescens strains 7MA20 (94\%) and 7MA12 (93\%) (O genotype) (Landa et al., 2002b) and MVW1 (P genotype), which were both detected on pea (De La Fuente et al., 2006). The next nearest neighbors were those of MVW1 (P genotype), both detected on pea. Further afield were the FTD1R36 and FFL1R8 groups (genotypes GHIJ). Fluorescent Pseudomonas spp. strains producing 2,4-DAPG exhibit considerable genetic and phenotypic diversity (McSpadden-Gardener et al., 2000). Our study is the first to isolate a novel phlD genotype from Pseudomonas spp. NJ134, indicating that geological distribution of $p h l D+$ may be a major factor for isolating a novel genotype in Korea.

DAPG-producing bacteria of different genotypes play a
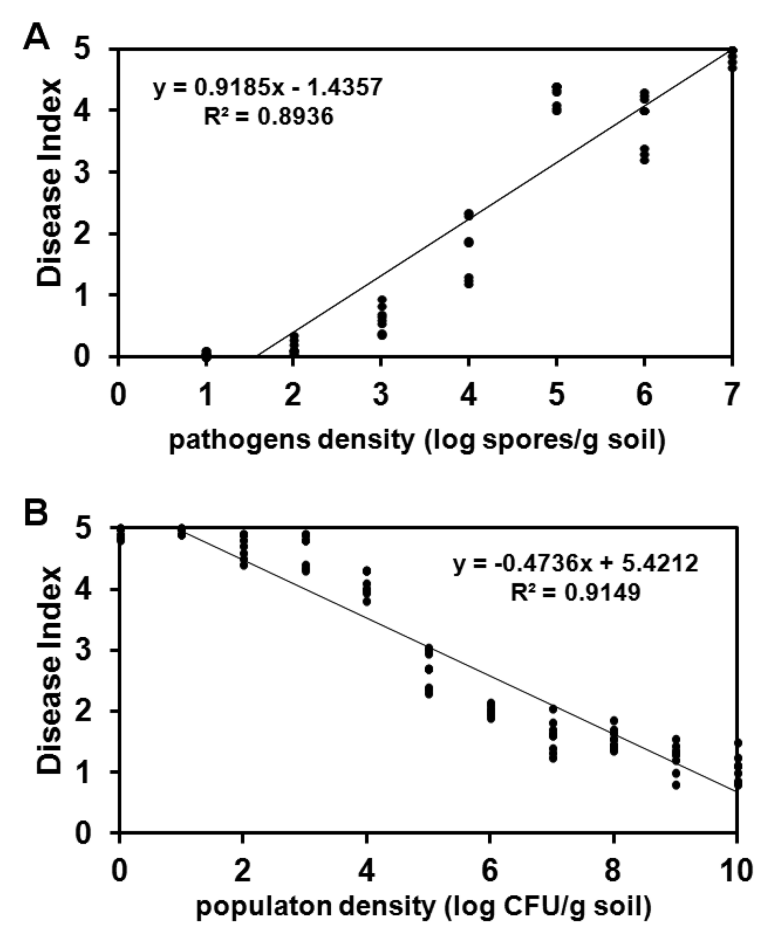

Fig. 4. A, Relationship between the rhizosphere population density of Fusarium oxysporum and tomato Fusarium wilt on roots. Tomato seedlings were treated with $F$. oxysporum at densities of approximately $10^{1}, 10^{2}, 10^{3}, 10^{4}, 10^{5}, 10^{6}$, and $10^{7}$ spore per $g$ of soil to achieve a range of population densities in the rhizosphere. B, Relationship between the rhizosphere population density of Pseudomonas strain $\mathrm{NJ} 134$ and that of $F$. oxysporum per population unit $\left(10^{5} \mathrm{CFU}\right)$. Tomato seedlings were treated with strain $\mathrm{NJ} 134$ at densities of approximately $10^{1}, 10^{2}, 10^{3}, 10^{4}$, $10^{5}, 10^{6}, 10^{7}, 10^{8}, 10^{9}$, and $10^{10} \mathrm{CFU}$ per $\mathrm{g}$ of soil to achieve a range of population densities in the rhizosphere. The disease index was as follows: $0=$ healthy plant, all leaves were green; $1=$ the first yellow leaf; $2=$ lower leaves yellow; $3=$ lower leaves dead and some upper leaves yellow; $4=$ upper leaves wilted, lower leaves dead; $5=$ dead plant. The experiment was conducted two times with 30 plants per treatment.

key role in agricultural environments, and their potential for use in sustainable agriculture is shown by in situ biological activities such as root colonization. In general, biocontrol approaches are highly effective under low disease pressure, but biocontrol efficacy of biopesticides is not satisfied under high disease pressure (Kim et al., 2010). We investigated the severity of tomato Fusarium wilt with inoculum doses of conidial spores from the pathogen (Fig. 4A). The pathogen was inoculated with infested soil (De Boer et al., 2003). The infested Fusarium wilt soil was used for F. oxysporum. The pathogen was cultured in aerated 10\% PDB (Difco Lab) medium at $25^{\circ} \mathrm{C}$. After 21 days of growth, cultures were filtered through sterile glass wool to remove mycelia mats. Microconidia were harvested by centrifugation at 8,000 $\times g$ for $20 \mathrm{~min}$, resuspended in $10 \mathrm{mM} \mathrm{MgSO}_{4}$, and mixed with a potting soil-sand mixture $(12: 5, \mathrm{v} / \mathrm{v})$ to different densities. 
Inoculated soil was incubated in polyethylene bags for 3-5 days at $25^{\circ} \mathrm{C}$ before use in the potting soil bioassays and then stored at $4{ }^{\circ} \mathrm{C}$. Inoculum viability of each fungi dosage was determined by serial dilution on a peptone pentachloronitribenzene (PCNB) medium for pathogens (Threlfall, 1972). Inoculums were prepared by dilution with noninfested soil. The experiment was conducted two times with 30 plants per treatment. The disease index $(0-5)$ was assayed in plants showing any wilt symptoms due to the pathogen (yellowing and dropping of leaves, vascular discoloration, or wilting). Stem sections from wilted plants were surfacedisinfested in $0.5 \%$ sodium hypochlorite and plated on PCNB medium to confirm the presence of the wilt pathogen.

After 2 weeks, the shoots languished, and the roots started to rot gradually and had a dark brown appearance. Tomato plants began to show their first leaf yellowing (disease index, 1) against $F$. oxysporum infection at a concentration of $1 \times$ $10^{4}$ spore $^{-1}$ of soil. A pathogen density $>1 \times 10^{5}$ spore $^{-1}$ of soil resulted in wilted upper leaves and dead lower leaves (disease index, 4) (Fig. 4A). However, $<1 \times 10^{4}$ spores/g of soil did not result in any visible symptoms. We determined the biocontrol efficacy of the novel phlD + NJ134 under highdisease pressure greenhouse conditions with different bacterial dosages of NJ134 grown in modified KB amended with $1 \%$ mannitol.

The new DAPG-producing NJ134 genotype was introduced at a dosage from $1 \times 10^{1}$ to $1 \times 10^{10}$ cells $\mathrm{g}^{-1}$ of soil into the infected $F$. oxysporum of $1 \times 10^{5}$ spore $\mathrm{g}^{-1}$ (Fig. 4B). The leaves of infected seedlings grown without NJ134 colonization became yellow, and plants wilted 2 weeks after pathogen application. Root cross sections of these infected tomato plants were characterized by dark red to black discoloration and rotting.

Tomato seedlings with roots colonized with $>1 \times 10^{9}$ cells g soil ${ }^{-1}$ NJ134 showed a disease index of 1.3 (Fig. 4B). Biocontrol efficacy of Fusarium wilt disease by NJ134 was dependent on the cell density applied. The optimal cell density to obtain effective control efficacy of Fusarium wilt was $>1 \times 10^{7.8}$ density (disease index, 1.6). The population densities ranged from up to $1 \times 10^{4}$ cells $\mathrm{g}^{-1}$ of soil, and the disease index ranged from 5.0 to 4.1. NJ134 did not show any phytotoxicity to tomato plants, even when they were treated with high concentrations. These results indicated that at least $1 \times 10^{8}$ of the NJ134 culture was required to effectively control tomato Fusarium wilt in plants. Previous studies with 2,4-DAPG-producing fluorescent Pseudomonas spp. showed the threshold density to be $10^{5} \mathrm{CFU} \mathrm{g} \mathrm{root}^{-1}$ for take-all decline in Washington State and the Netherlands (Weller et al., 2002).

Biocontrol efficacy was evaluated with the $10^{8} \mathrm{CFU} / \mathrm{ml}$ NJ134 batch cultures (Fig. 5). Field assays were run under greenhouse soil, located in Naju (Joennam Province, Korea), using 18-20 leaf stage tomato plants (Unicorn, Hungnong

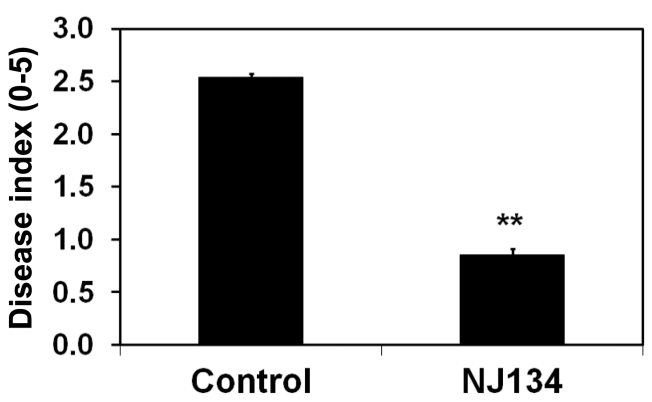

Fig. 5. Efficacy of a bacterial suspension on tomato wilt disease under field conditions. Bacteria were grown for 7 days in KB. A bacterial suspension containing $1 \times 10^{8} \mathrm{CFU} / \mathrm{ml}$ was drenched four times for 60 days after transplanting. Plants raised from bacterial-treated and untreated seedling were wound-inoculated with $F$. oxysporum at $10^{6} \mathrm{CFU} / \mathrm{mL}$ when tomato plants were 70 days old in the greenhouse. The disease index was as follows: $0=$ healthy plant, all leaves were green; 1 = first leaf yellow; $2=$ lower leaves yellow; 3 = lower leaves dead and some upper leaves yellow; $4=$ upper leaves wilted and lower leaves dead; $5=$ dead plant. ${ }^{* *}$ significant at $1 \%$ level by $t$-test.

Seeds, Seoul, South Korea), during spring and summer. The introduced NJ134 suspensions of $10^{8} \mathrm{CFU} / \mathrm{ml}$ were drenched four times for 60 days after transplanting. Plants raised from bacteria-treated and untreated seedling were wound-inoculated with $F$. oxysporum at $10^{6} \mathrm{spore} / \mathrm{g}$ when tomato plants were 70 days old. Disease was monitored for 6-8 weeks and assayed as the index (0-5) of plants showing any wilt symptoms due to the pathogen (yellowing and dropping of leaves, vascular discoloration, and wilting). Stem sections of wilted plants were surface disinfected with $0.5 \%$ sodium hypochlorite and plated on PCNB medium to confirm the presence of the wilt pathogen. The plants treated with NJ134 showed the disease index ranged from 0.7 to 1.0 , whereas it averaged 2.5 in untreated plants. The untreated plants showed severe disease symptoms; the first or lower leaves died and some upper leaves turned yellow, whereas the plants treated with the NJ134 DAPG producer were relatively healthy or only weakly yellow.

In summary we demonstrate that a pseudomonad isolated from Korean soils was of a new genotype different from those classified previously from Europe and North America. The production of DAPG correlated with the presence of the phlD gene. Isolate $\mathrm{NJ} 134$ had potent in vitro and in vivo antifungal activity against fungal plant pathogens that was demonstrated in commercial soils for Fusarium wilt of tomato Maximization of biocontrol efficacy of this strain will required further evaluation of the role played by DAPG and the formulations for growth and application under field conditions.

\section{Acknowledgement}

This work was supported by a grant from the Korea 
Institute of Planning and Evaluation for Technology in Food, Agriculture, Forestry, and Fisheries (311019-03-1HD120), Ministry for Food, Agriculture, Forestry and Fisheries, Republic of Korea.

\section{References}

Brisbane, P. G., Janik, L. J., Tate, M. E. and Warren, R. F. O. 1987. Revised structure for the phenazine antibiotic from Pseudomonas fluorescens 2-79. Antimicrob. Agents Chemother. 31: 1967-1971.

Broadbent, D., Mabelis, R. P. and Spenser, H. 1976. C-acetyphloroglucinols from Pseudomonas fluorescens. Phytochem. 15: 1785.

Cho, J.-C. and Tiedje, J. M. 2000. Biogeography and degree of endemicity of fluorescent Pseudomonas strains in soil. Appl. Environ. Microbiol. 66:5448-5456.

Cook, R. J. 1993. Making greater use of introduced microorganisms for biological control of plant pathogens. Annu. Rev. Phytopathol. 31:53-80.

De Boer, M., Bom, P., Kindt, F., Keurentjes, J. J., van der Sluis, I., van Loon, L. C. and Bakker, P. A. 2003. Control of Fusarium wilt of radish by combining Pseudomonas putida strains that have different disease-suppressive mechanisms. Phytopathology 93:626-632.

De La Fuente, L., Mavrodi1, D. V., Landa, B. B., Thomashow, L. S. and Weller, D. M. 2006. phlD-based genetic diversity and detection of genotypes of 2,4-diacetylphloroglucinol-producing Pseudomonas fluorescens. FEMS Micro. Ecol. 56:64-78.

Dwivedi, D. and Johri, B. N. 2003. Antifungals from fluorescent pseudomonads: Biosynthesis and regulation. Curr. Sci. 85: 1693-1703.

Gerber, N. N. 1969. New microbial phenazines. J. Heterocyclic Chem. 6:297-300.

Haas, D., Keel, C., Laville, J., Maurhofer, M., Oberhansli, T., Schnider, U., Voisard, C., Wuthrich, B. and Défago, G. 1991. Secondary metabolites of Pseudomonas fluorescens strain CHA0 involved in the suppression of root diseases. In: Advances in molecular genetics of plant-microbe interactions, ed. by H. Hennecke and D. P. S. Verma, pp. 450-456. Kluwer Academic Publishers, Hingham, Mass.

Hashimoto, M. and Hattori, K. 1966a. Isopyrrolnitrin: a metabolite from Pseudomonas. Bull. Chem. Soc. Jpn. 39:410.

Hashimoto, M. and Hattori, K. 1966b. Oxypyrrolnitrin: a metabolite of Pseudomonas. Chem. Pharm. Bull. 14:1314-1316.

Hays, E. E., Wells, I. C., Katzman, P. A., Cain, C. K., Jacobs, F. A., Thayer, S. A., Doisy, E. A., Gaby, W. L., Roberts, E. C., Muir, R. D., Carroll, C. J., Jones, L. R. and Wade, N. J. 1945. Antibiotic substances produced by Pseudomonas aeruginosa. J. Biol. Chem. 159:725-750.

Imanaka, H., Kousaka, M., Tamura, G. and Arima, K. 1965. Studies on pyrrolnitrin, a new antibiotic III. Structure of pyrrolnitrin. J. Antibiot. Ser. 18:207-210.

Jarvis, W. R. 1988. Fusarium crown and root rot of tomatoes. Phytoprotection 69:49-64.
Jones, J. B., Jones, J. P., Stall, R. E. and Zitter, T. A. 1991. Compendium of tomato diseases. American Phytopathological Society, St. Paul, MN.

Keel, C., Weller, D. M., Natsch, A., Défago, G., Cook, R. J. and Thomashow, L. S. 1996. Conservation of the 2,4-diacetylphloroglucinol biosynthesis locus among fluorescent Pseudomonas strains from diverse geographic locations. Appl. Environ. Microbiol. 62:552-562.

Keel, C., Wirthner, P. H., Oberhansli, T. H., Voisard, C., Burger, Haas, U. D. and Défago, G. 1990. Pseudomonads as antagonists of plants pathogens in the rhizosphere: role of the antibiotic 2,4-diacetylphloroglucinol in the suppression of black root rot of tobacco. Symbiosis 9:327-341.

Kim,Y. C., Lee, J. H., Bae, Y.-S. Sohn, B.-K. and Park, S. K. 2010. Development of effective environmentally-friendly approaches to control Alternaria blight and anthracnose diseases of Korean ginseng. Eur. J. Plant Pathol. 127:443-450.

Larkin, R. P. and Fravel, D. R. 1998. Efficacy of various fungal and bacterial biocontrol organisms for control of Fusarium wilt of tomato. Plant Dis. 82:1022-1028.

Landa, B. B., de Werd, H. A. E., McSpadden-Gardener, B. B. and Weller, D. M. 2002a. Comparison of three methods for monitoring populations of different genotypes of 2,4-diacetylphloroglucinol-producing Pseudomonas fluorescens in the rhizosphere. Phytopathology 92:129-137.

Landa, B. B., Mavrodi, O. V., Raaijmakers, J. M., McSpaddenGardener, B. B., Thomashow, L. S. and Weller, D. M. 2002b. Differential ability of genotypes of 2,4-diacetylphloroglucinol-producing Pseudomonas fluorescens to colonize the roots of pea. Appl. Environ. Microbiol. 68:3226-3237.

Mavrodi, O. V., McSpadden-Gardener, B. B., Mavrodi, D. V., Bonsall, R. F., Weller, D. M. and Thomashow, L. S. 2001. Genetic diversity of phlD from 2,4-diacetylphloroglucinolproducing fluorescent Pseudomonas spp. Phytopathology 91:35-43.

McSpadden-Gardener, B. B., Gutierrez, L. J., Joshi, R., Edema, R. and Lutton, E. 2005. Distribution and biocontrol potential of phlD pseudomonads in corn and soybean fields. Phytopathology 95:715-724.

McSpadden-Gardener, B. B., Mavrodi, D. V., Thomashow, L. S. and Weller, D. M. 2001. A rapid polymerase chain reactionbased assay characterizing rhizosphere populations of 2,4diacetylphloroglucinol-producing bacteria. Phytopathology 91:44-54.

McSpadden-Gardener, B. B., Schroeder, K. L., Kalloger, S. E., Raaijmakers, J. M., Thomashow, L. S. and Weller, D. M.. 2000. Genotypic and phenotypic diversity of phlD-containing Pseudomonas strains isolated from the rhizosphere of wheat. Appl. Environ. Microbiol. 66:1939-1946.

Tamura, K., Dudley, J., Nei, M. and Kumar, S. 2007. MEGA4: Molecular Evolutionary Genetics Analysis (MEGA) software version 4.0. Mol. Biol. Evol. 24:1596-1599.

Thomashow, L. S., Weller, D. M., Bonsall, R. F. and Pierson, L. S. 1990. Production of the antibiotic phenazine 1-carboxylic acid by fluorescent Pseudomonas species in the rhizosphere of wheat. Appl. Environ. Microbiol. 56:908-912. 
Threlfall, R. J. 1972. Effect of pentachloronitrobenzene (PCNB) and other chemicals on sensitive and PCNB-resistant strains of Aspergillus nidulans. J. Gen. Microbiol. 71:173-180.

Weisburg, W. G., Barns, S. M., Pelletier, D. A. and Lane, D. J. 1991. 16S ribosomal DNA amplification for phylogenetic study. J. Bacteriol. 173:697-703.

Weller, D. M., Raaijmakers, J. M., McSpadden-Gardener, B. B. and Thomashow, L. S. 2002. Microbial populations responsi- ble for specific soil suppressiveness to plant pathogens. Annu. Rev. Phytopathol. 40:309-348.

Woodruff, H. B. 1988. Natural products from microorganisms. Science 208:1225-1229.

Wratten, S. J., Wolfe, M. S., Anderson, R. J. and Faukner, D. J. 1977. Antibiotic metabolites from a marine pseudomonad. Antimicrob. Agents Chemother. 11:411-414. 